\title{
Pelanggaran Hak Konstitusional Mengenai Multitafsir Pasal 164 Ayat (3) Undang-Undang Nomor 13 Tahun 2003 Tentang Ketenagakerjaan
}

\author{
Irma Dewi Anggraini \\ Magister Hukum Fakultas Hukum Universitas Islam Indonesia Yogyakarta Indonesia \\ Jln. Cik Di Tiro No. 1 Yogyakarta Indonesia \\ irmadewi96@gmail.com
}

\begin{abstract}
This study raises issues of first, regarding the violation of constitutional rights that occurred in Article 164 paragraph (3) of Law Number 13 of 2003 on Manpower. Second, as a result of the multiple interpretations that occurred in Article 164 paragraph (3) of Law Number 13 of 2003 on Manpower. The research method used in this research is normative juridical. The approach used in this research is a statutory approach. The results of the research are first, there are multiple interpretations in Article 164 paragraph (3) of Law Number 13 of 2003 on Manpower, so that the rights of workers are violated by employers. Second, due to multiple interpretations of Article 164 paragraph (3) of Law Number 13 of 2003 on Manpower (i) employers can misuse it to give layoffs to workers/laborers; (ii) employers in terms of doing layoffs must be interpreted as a last resort; (iii) a review is submitted; (iv) employers should be held accountable for the loss of livelihoods for workers.
\end{abstract}

Key Words: Constitutional rights; multiple interpretations

\begin{abstract}
Abstrak
Penelitian ini mengangkat permasalahan, pertama, mengenai pelanggaran hak konstitusional yang terjadi dalam Pasal 164 ayat (3) Undang-Undang Nomor 13 Tahun 2003 tentang Ketenagakerjaan. Kedua, akibat dari multitafsir yang terjadi pada Pasal 164 ayat (3) Undang-Undang Nomor 13 Tahun 2003 tentang Ketenagakerjaan. Metode penelitian yang digunakan dalam penelitian ini adalah yuridis normatif. Pendekatan yang dipergunakan dalam penelitian adalah pendekatan perundang-undangan (statue approach). Hasil penelitian bahwa, pertama, terdapat multitafsir dalam Pasal 164 ayat (3) Undang-Undang Nomor 13 Tahun 2003 tentang Ketenagakerjaan, sehingga hak-hak pekerja dilanggar oleh pengusaha. Kedua, akibat adanya multitafsir terhadap Pasal 164 ayat (3) UndangUndang Nomor 13 Tahun 2003 tentang Ketenagakerjaan (i) dapat disalahgunakan oleh pengusaha untuk memberikan PHK kepada pekerja/buruh; (ii) pengusaha dalam hal melakukan PHK harus dimaknai sebagai upaya terakhir; (iii) diajukan Peninjauan Kembali; (iv) pengusaha harus bertanggungjawab atas hilangnya mata pencaharian para pekerja.
\end{abstract}

Kata-kata Kunci: Hak konstitusional; multitafsir 


\section{Pendahuluan}

Negara Kesatuan Republik Indonesia (NKRI) merupakan negara yang merdeka, dan mempunyai konstitusi yang menjelaskan bahwa Negara Indonesia adalah negara hukum. Hal ini menerangkan bahwa setiap perbuatan yang dilakukan oleh setiap orang yang berstatus Warga Negara Indonesia (WNI) mempunyai hak konstitusional yang harus diberikan negara dalam bentuk perlindungan demi terciptanya keharmonisan kehidupan bermasyarakat.

Setiap WNI untuk menunjang kehidupan, diperlukan sarana untuk memenuhi segala kebutuhan yang diperlukannya, dengan cara memperoleh pekerjaan. Dari pekerjaan ini setiap WNI dapat menerima penghasilan untuk memenuhi segala kebutuhan sehari-hari. Pekerja yang telah mempunyai pekerjaan pun tidak lepas dari berbagai persoalan yang terjadi dalam hubungan kerja, hal ini mengakibatkan sering terjadinya konflik antara pengusaha atau pemberi kerja dengan pekerja. Persoalan ini mempunyai tingkatan masingmasing mulai dari tingkat terendah yaitu peringatan hingga terberat dengan adanya Pemutusan Hubungan Kerja (PHK).

Salah satu contoh adanya konflik dalam Pemutusan Hubungan Kerja (PHK) terjadi di suatu Hotel yang ada di Bandung dan menimbulkan polemik yang sangat serius karena PHK ini dilakukan dengan suatu alasan yang tidak sesuai dengan aturan yang berlaku. Hotel Papandayan berdiri pada 1994, sebelumnya tidak pernah ada perselisihan buruh dengan manajemen. Namun pada 18 November 2009 lalu, pihak hotel mengeluarkan surat keputusan mengenai pemutusan hubungan kerja dengan para karyawan dengan alasan hotel akan direnovasi untuk satu hingga tiga tahun kedepan. ${ }^{1}$ Surat Keputusan Direksi yang dikeluarkan oleh pihak PT Citragraha Nugratama No. 01/HPB/SK-Dir/IX/2009 tentang penutupan operasional Hotel Papandayan Bandung 18 November 2009 dipegang oleh Direksi Marcella Sapardan ini merupakan awal mula terjadi permasalahan antara pihak pekerja dengan pihak hotel. Dalam surat tersebut disebutkan alasan penutupan karena hotel akan direnovasi total untuk menjadi status hotel dari bintang 4 menjadi bintang 5, penutupan diberlakukan mulai 30 November 2009 hingga selesai renovasi yang tidak disebutkan waktunya. Atas surat tersebut terjadi perselisihan antara pihak pekerja dengan pihak hotel, mereka pun telah melakukan pertemuan bipartite dan masih menemui jalan buntu. ${ }^{2}$

Tindakan dari pihak pengusaha ini sangat merugikan pihak pekerja, hal ini tidak sesuai dengan Pasal 164 ayat (3) Undang-Undang Nomor 13 Tahun 2003 
tentang Ketenagakerjaan. Berlandaskan pada hak-hak yang ada dalam UUD 1945 terutama Pasal 28D ayat (2) UUD 1945 yang memberikan jaminan atas pekerjaan menyebutkan bahwa "Setiap orang berhak untuk bekerja serta mendapat imbalan dan perlakuan yang adil dan layak dalam hubungan kerja". Berdasar rumusan tersebut maka jaminan hak untuk bekerja dan mendapatkan imbalan yang adil sesuai pekerjaan yang dijalani. Jaminan hak untuk bekerja ini melindungi para pekerja dari tindakan sewenang-sewenang pengusaha untuk melakukan tindakan pemecatan yang tidak sesuai dengan prosedur yang ada.

Permasalahan mengenai Pemutusan Hubungan Kerja yang terjadi di Hotel Papandayan yang berada di Bandung ini hingga diajukan sebagai judicial review ke Mahkamah Konstitusi ini menjadi polemik yang perlu untuk diteliti, karena persoalan mengenai hak setiap warga negara harus dilindungi oleh negara sebagai pihak yang bertugas melindungi setiap warga negaranya. Berdasarkan uraian latar belakang tersebut diatas, penulis akan mengkaji lebih dalam mengenai permasalahan yang berkaitan dengan pengujian Undang-Undang terhadap UUD 1945 dengan judul "Pelanggaran Hak Konstitusional Mengenai Multitafsir Pasal 164 ayat (3) Undang-Undang Nomor 13 Tahun 2003 tentang Ketenagakerjaan".

\section{Rumusan Masalah}

1. Bagaimana Pelanggaran Hak Konstitusional yang terjadi dalam Pasal 164 ayat (3) Undang-Undang Nomor 13 Tahun 2003?

2. Bagaimana akibat dari multitafsir yang terjadi pada Pasal 164 ayat (3) UndangUndang Nomor 13 Tahun 2003?

\section{Tujuan Penelitian}

1. Untuk mengetahui Pelanggaran Hak Konstitusional yang terjadi dalam Pasal 164 ayat (3) Undang-Undang Nomor 13 Tahun 2003.

2. Untuk mengetahui akibat multitafsir yang terjadi pada Pasal 164 ayat (3) Undang-Undang Nomor 13 Tahun 2003.

\section{Metode Penelitian}

Penelitian ini menggunakan pendekatan yuridis normatif, dengan menggunakan hukum primer $^{3}$ terutama mengenai peraturan perundangundangan. Undang-Undang Nomor 13 Tahun 2003 tentang Ketenagakerjaan. Dalam penelitian ini data dikumpulkan melalui studi terhadap dokumen dan

${ }^{3}$ C.F.G. Sunaryati Hartono, Penelitian Hukum di Indonesia Pada Akhir Abad ke-20, Alumni, Bandung, 1994, 
studi kepustakaan. Penelitian terhadap bahan-bahan hukum sekunder yang berasal dari sumber kepustakaan berupa buku, artikel, dan wawancara sebagai pelengkap. Data-data tersebut akan dianalisis secara deskriptif kualitatif.

\section{Hasil Penelitian dan Pembahasan}

Negara Indonesia sebagai negara hukum memiliki lembaga-lembaga peradilan yang memiliki peran sebagai penegak keadilan atau apparat penegak hukum. Istilah negara hukum merupakan terjemahan langsung dari rechsstaat. Konsep rechsstaat bertumpu atas sistem hukum kontinental yang disebut civil law, karakteristik civil law adalah administratif. Adapun ciri-ciri rechsstaat adalah:
a. Adanya Undang-Undang Dasar atau konstitusi yang memuat ketentuan tertulis tentang hubungan antara penguasa dan rakyat;
b. Adanya pembagian kekuasaan negara;
c. Diakui dan dilindunginya hak-hak kebebasan rakyat.

Ciri-ciri ini menunjukkan bahwa ide rechsstaat adalah pengakuan dan perlindungan terhadap hak-hak asasi manusia yang bertumpu atas prinsip kebebasan dan persamaan. Adanya Undang-Undang Dasar akan memberikan jaminan konstitusional terhadap asas kebebasan dan persamaan. ${ }^{4}$

Pengertian lain dari negara hukum menurut Wirjono Prodjodikoro, negara hukum berarti suatu negara yang di dalam wilayahnya adalah:

a. Semua alat-alat perlengkapan dari negara, khususnya alat-alat perlengkapan dari pemerintah dalam tindakannya baik terhadap para warga negara maupun dalam saling berhubungan masing-masing, tidak boleh sewenang-wenang, melainkan harus memperhatikan peraturanperaturan hukum yang berlaku;

b. Semua orang (penduduk) dalam hubungan kemasyarakatan harus tunduk pada peraturan-peraturan hukum yang berlaku. ${ }^{5}$

Lembaga-lembaga ini dibersihkan dari setiap intervensi dari Lembaga legislatif, eksekutif maupun Lembaga lainnya. Kekuasaan kehakiman itu dilakukan oleh seorang hakim. Hakim disini adalah pejabat peradilan negara yang diberi kekuasaan oleh undang-undang untuk mengadili. Maksud mengadili tersebut adalah sebuah atau serangkaian Tindakan hakim yang digunakan untuk mengadili sesuai dengan ketentuan undang-undang yang berlaku. Kemudian didalam Mahkamah Konstitusi mempunyai kewenangan dalam tingkat pertama dan terakhir dan putusan Mahkamah Konstitusi bersifat final, yaitu langsung

\footnotetext{
${ }^{4}$ Ni'matul Huda, Hukum Tata Negara Indonesia, PT. Raja Grafindo Persada, Jakarta, 2005, hlm. 73-74.

5 Wirjono Prodjodikoro, Asas-asas Ilmu Negara dan Politik, Eresco, Bandung, 1971, hlm. 38 dikutip dari Ni'matul Huda, Hukum Tata Negara Indonesia, PT. Raja Grafindo Persada, Jakarta, 2005, hlm. 75.
} 
mempunyai kekuatan hukum tetap dan tidak terdapat upaya hukum untuk mengubahnya. ${ }^{6}$

Penegakan hukum di Indonesia dan peranan hakim dalam mengadili suatu perkara, dapat memberikan arah kemana dan siapa yang harus menjamin Hak Setiap Warga Negara Indonesia. Hal ini tentu sangat dibutuhkan bagi setiap Warga Negara Indonesia. Hal ini tentu sangat dibutuhkan bagi setiap Warga Negara yang hak-haknya kurnag dipenuhi atau bahkan dilanggar oleh salah satu atau beberapa pihak demi mengambil keuntungan bagi diri sendirinya. Hak-hak yang diberikan oleh negara ini pun sudah tertuang dalam UUD 1945 yang bisa disebut dengan Hak Konstitusional.

Hak Konstitusional yang ada dalam UUD NRI Tahun 1945 telah banyak mengatur mengenai ketentuan dalam hidup bermasyarakat. Salah satu ketentuan yang sangat penting untuk diperhatikan oleh pemerintah adalah mengenai permasalahan pekerjaan yang merupakan masalah yang sangat penting bagi keberlangsungan kehidupan warga negara. Apabila terdapat permasalahan pekerjaan yang merugikan warga negara, negara harus tampil sebagai penengah.

Pasal yang menjelaskan mengenai Hak Atas Kerja dan Penghidupan Layak bagi kemanusiaan adalah Pasal 27 ayat (2) Undang-Undang Dasar 1945 menyatakan, "Tiap-tiap warga negara berhak atas pekerjaan dan penghidupan yang layak bagi kemanusiaan". Selanjutnya Pasal 28D ayat (2) Undang-Undang Dasar 1945 tentang Hak untuk bekerja dan mendapat imbalan dan perlakuan yang adil dan layak dalam hubungan kerja yang menyatakan, "Setiap orang berhak untuk bekerja serta mendapat imbalan dan perlakuan yang adil dan layak dalam hubungan kerja". Pasal lain yang menjelaskan mengenai hal tersebut selanjutnya adalah Pasal 28I ayat (2) Undang-Undang Dasar 1945 mengenai Hak untuk tidak diperbudak yang menyatakan, "Setiap orang bebas dari perlakuan yang bersifat diskriminatif atas dasar apapun dan berhak mendapatkan perlindungan terhadap perlakuan yang bersifat diskriminatif".

Ketentuan Pasal Undang-Undang Dasar 1945 a quo dalam kaitannya dengan hak konstitusional warga negara dalam bekerja termasuk hak yang harus dilindungi negara. Bahkan pemerintah harus mengawasi tindakan yang terindikasi akan terjadi pelanggaran HAM atau tindakan yang akan merugikan setiap warga negara terlebih mengenai pekerjaan yang sedang mereka jalankan.

Kasus nyata yang terkait hak-hak warga negara dalam bekerja adalah Pemutusan Hubungan Kerja yang terlah terjadi pada Hotel Papandayan di Bandung, Jawa Barat. Awal kasus ini terjadi Ketika adanya Surat Keputusan Direksi yang dikeluarkan oleh pihak PT. Citragraha Nugratama No.01/HPB/SK-

${ }^{6}$ Ni'matul Huda, Negara Hukum, Demokrasi \& Judicial Review, UII Press, Yogyakarta, 2005, hlm. 122. 
Dir/IX/2009 tentang penutupan operasional Hotel Papandayan 18 November 2009.7

Surat tersebut menyebutkan bahwa alasan penutupan karena hotel akan direnovasi total untuk menjadi status hotel dari bintang 4 menjadi bintang 5, penutupan diberlakukan mulai 30 Novemnber 2009 hingga selesai renovasi yang tidak disebutkan waktunya. Atas surat tersebut terjadi perselisihan antara pihak hotel mereka pun telah melakukan pertemuan bipartit dan masih menemui jalan buntu. Hingga akhirnya sampai ke Pengadilan Hubungan Industrial dan Kasasi di Mahkamah Agung tetapi hasil keputusan yang dikeluarkan oleh Pengadilan tetap memberikan PHK kepada para pekerja. ${ }^{8}$

Berdasarkan ketentuan Pasal 1 angka 14 Undang-Undang Nomor 13 Tahun 2003, hubungan kerja adalah hubungan antara pengusaha dengan pekerja/buruh berdasarkan perjanjian kerja, yang mempunyai unsur pekerjaan, upah, dan perintah. Unsur-unsur perjanjian kerja, antara lain:

a. Adanya pekerjaan (arbeid);

b. Di bawah perintah/ gezag ver houding (maksudnya buruh melakukan pekerjaan atas perintah majikan, sehingga bersifat subordinasi);

c. Adanya upah tertentu/loan;

d. Dalam waktu (tjid) yang ditentukan (dapat tanpa batas waktu/pensiun atau berdasarkan waktu tertentu). ${ }^{9}$

Dalam Hubungan Kerja, pengusaha/pemberi kerja dan pekerja tidak lepas dari hak dan kewajiban para pihak. Seperti yang telah diketahui hak dari pengusaha merupakan kewajiban bagi pekerja, dan sebaliknya kewajiban bagi pengusaha adalah hak bagi pekerja. Pada umumnya, kewajiban telah diatur dalam hukum yang telah ditetapkan oleh pemerintah dalam rangka melindungi para pekerja, atau apabila ingin diatur lebih khusus, biasanya diatur dengan cara perundingan dengan menyusun perjanjian kerja bersama atau diatur sendiri di dalam peraturan perusahaan.

Dalam hal memenuhi kewajiban dan hak pada masing-masing pihak, telah diatur kewajiban pengusaha, seperti: menyediakan pekerjaan yang akan dilakukan pekerja dan membayar upah atau imbalan atas pekerjaan yang dilakukan oleh pekerja. Dan kewajiban pekerja adalah melakukan pekerjaan dengan sebaik-baiknya atas petunjuk atau perintah yang diberikan oleh pengusaha, sesuai dengan waktu yang ditentukan. ${ }^{10}$

\footnotetext{
${ }^{7}$ https://nasional.tempo.co/read/217411/karyawan-hotel-papandayan-bandung-kembaliadukan-phk

${ }^{8}$ Ibid.

${ }_{9}^{9}$ Asri Wijayanti, Hukum Ketenagakerjaan Pasca Reformasi, Sinar Grafika, Jakarta, 2014, hlm. 36.

10 Aloysius Uwiyono, dkk., Asas-asas Hukum Perburuban, PT RajaGrafindo Persada, Jakarta, 2014, hlm. 62-
} 63. 
Permohonan para Pemohon disini adalah untuk menguji konstitusionalitas

Pasal 164 ayat (3) Undang-Undang Nomor 13 Tahun 2003 tentang Ketenagakerjaan (Lembaran Negara Republik Indonesia Tahun 2003 Nomor 39, Tambahan Lembaran Negara Republik Indonesia Nomor 4279, selanjutnya disebut UU 13/2003) terhadap Pasal 28D ayat (2) Undang-Undang Dasar Negara Republik Indonesia Tahun 1945 (selanjutnya disebut UUD 1945).

Adapun Amar Putusan Mahkamah Konstitusi, sebagai berikut: ${ }^{11}$

1. Permohonan para Pemohon dikabulkan untuk Sebagian;

2. Menyatakan Pasal 164 ayat (3) Undang-Undang Nomor 13 Tahun 2003 tentang Ketenagakerjaan (Lembaran Negara Republik Indonesia Tahun 2003 Nomor 39, Tambahan Lembaran Negara Republik Indonesia Nomor 4279) bertentangan dengan Undang-Undang Dasar Negara Republik Indonesia Tahun 1945 sepanjang frasa "perusahaan tutup" tidak dimaknai "perusahaan tutup permanen atau perusahaan tutup tidak untuk sementara waktu";

3. Menyatakan Pasal 164 ayat (3) Undang-Undang Nomor 13 Tahun 2003 tentang Ketenagakerjaan (Lembaran Negara Republik Indonesia Tahun 2003 Nomor 39, Tambahan Lembaran Negara Republik Indonesia Nomor 4279) pada frasa "perusahaan tutup" tidak memiliki kekuatan hukum mengikat sepanjang tidak dimaknai "perusahaan tutup permanen atau perusahaan tutup tidak untuk sementara waktu";

4. Memerintahkan pemuatan Putusan ini dalam Berita Negara Republik Indonesia sebagaimana mestinya;

5. Menolak permohonan para Pemohon untuk selain dan selebihnya.

Dari Amar Putusan Mahkamah Konstitusi tersebut di atas, sebelumnya hakim memberikan pertimbangan atau dasar konstitusional yang menyatakan bahwa:

Para Pemohon pada intinya, mengajukan jika Pasal 164 ayat (3) UU 13/2003 yang menyatakan:

"Pengusaha dapat melakukan pemutusan hubungan kerja terhadap pekerja/buruh karena perusahaan tutup bukan karena mengalami kerugian 2 (dua) tahun berturutturut atau bukan karena keadaan memaksa (force majeur) tetapi perusahaan melakukan efisiensi dengan ketentuan pekerja/buruh berhak atas uang pesangon sebesar 2 (dua) kali ketentuan Pasal 156 ayat (2), uang penghargaan masa kerja sebesar 1 (satu) kali ketentuan Pasal 156 ayat (3), dan uang penggantian hak sesuai ketentuan Pasal 156 ayat (4)"

bertentangan dengan Pasal 28D ayat (2) UUD 1945 yang menyatakan, "Setiap orang berhak untuk bekerja serta mendapat imbalan dan perlakuan yang adil dan layak dalam hubungan kerja".

11 Putusan Mahkamah Konstitusi Nomor 19/PUU-IX/2011 hlm. 59 
Kata "efisiensi" yang terdapat dalam Pasal 164 ayat (3) tersebut tidak dapat diartikan bahwa hal tersebut menjadi dasar perusahaan untuk melakukan PHK terhadap pekerja atau juga "mengefisiensikan biaya tenaga kerja" dengan cara memutuskan hubungan pekerja yang ada, namun harus diartikan bahwa PHK dapat dilakukan perusahaan apabila perusahaan tutup, dan tutupnya perusahaan adalah sebagai bentuk efisiensi, atau dengan kata lain pengusaha melakukan efisiensi dengan cara menutup perusahaan. Hal ini pun mempunyai arti frasa "perusahaan tutup" termasuk dalam penafsiran penutupan sementara untuk melakukan renovasi dalam rangka melakukan efisiensi.

Pemutusan Hubungan Kerja (PHK) harus dilakukan sebagai pilihan terakhir sebagai upaya untuk melakukan efisiensi perusahaan setelah sebelumnya dilakukan upaya-upaya yang lain dalam rangka efisiensi tersebut. Berdasarkan hal tersebut, menurut Mahkamah, perusahaan tidak dapat melakukan PHK sebelum menempuh upaya-upaya sebagai berikut: (a) mengurangi upah dan fasilitas pekerja tingkat atas, misalnya tingkat manajer dan direktur; (b) mengurangi shift; (c) membatasi/menghapuskan kerja lembur; (d) mengurangi jam kerja; (e) mengurangi hari kerja; (f) meliburkan atau merumahkan pekerja/buruh secara bergilir untuk sementara waktu; (g) tidak atau memperpanjang kontrak bagi pekerja yang sudah habis masa kontraknya; (h) memberikan pension bagi yang sudah memenuhi syarat. Hal ini berarti pengusaha harus mematuhi aturan agar hak-hak para pekerja terpenuhi dan pengusaha disini diberi amanah dari negara untuk melindungi hak-hak pekerja, karena pada dasarnya negara telah menjamin perlindungan HAM bagi warga negara.

Pihak yang sewenang-wenang dalam kasus ini adalah Hotel Papandayan yang terletak di Bandung, dimana pihak pengusaha melakukan Pemutusan Hubungan Kerja secara sepihak dengan alasan yang merugikan, pasalnya pihak hotel hanya menututp melakukan renovasi, tidak ada kerugian yang dialami pihak pengusaha bahkan tidak ada pelanggaran yang dilakukan oleh para pekerja.

Bukti bahwa pihak pengusaha melakukan tindakan sewenang-wenang adalah dengan adanya fakta bahwa sebelum adanya UU Nomor 13 Tahun 2003 tentang Ketenagakerjaan ini, terjadi kasus di Hotel Regent Jakarta pada 2001 yang tutup karena banjir selama hampir 2 tahun. Walaupun force majeur dan tidak memiliki persiapan dan cadangan dana namun tidak terjadi pemutusan hubungan kerja. Sebagian pekerja dirumahkan dan pengusaha tetap membayarkan kewajibannya walaupun hanya berupa hak-hak normatif sambil menunggu proses renovasi selesai, dan sebagian lainnya diperbantukan dalam 
proyek renovasi. ${ }^{12} \mathrm{Hal}$ ini membuktikan bahwa alasan perusahaan tutup disini hanya untuk memberi PHK untuk para pekerja.

Kasus ini terjadi dalam Hotel Papandayan ini sangat melanggar Prinsipprinsip Negara Hukum yang pada khususnya dalam Perlindungan Hak-hak Asasi Manusia (HAM), sedangkan kasus force majeur yang terjadi di Hotel Regent Jakarta pada 2001 sangat menjunjung tinggi Prinsip dalam Perlindungan Hak-hak Asasi Manusia (HAM), walaupun pada saat itu belum lahir perlindungan secara tertulis dalam sebuah UU.

Keterangan ahli yang dihadirkan oleh pemohon juga menguatkan pernyataan bahwa lemahnya pengaturan UU tentang Ketenagakerjaan ini, pasalnya dari berbagai penelitian yang dilakukan sejak 2005 terkait lahirnya UU Nomor 13 Tahun 2003 menunjukkan kecenderungan pengurangan kesempatan kerja akibat diterapkannya sistem kerja kontrak dan outsourcing serta kemudahan untuk merekrut dan memecat tenaga kerja. ${ }^{13}$ Pemerintah dan DPR pun dalam keterangannta menyatakan bahwa Tindakan PHK ini adalah tindakan yang tidak tepat dan tidak mematuhi secara benar tentang pemenuhan hak-hak pekerja/buruh, karena pada saat renovasi perusahaan (Hotel Papandayan) dapat dimungkinkan operasional perusahaan terhenti, tetapi terhentinya operasional perusahaan tidaklah sama dengan perusahaan tutup.

Mahkamah Konstitusi pada mulanya memang tidak dikenal atau dengan kata lain merupakan hal yang masih baru. Oleh karena itu, ketika UUD 1945 dirumuskan, gagasan Mahkamah Konstitusi ini belum muncul, banyak perdebatan ketika merumuskan UUD 1945 mengenai perlu tidaknya UUD 1945 mengakomodir gagasan hak uji materiil ke dalam kekuasaan kehakiman.

Mahkamah dalam hal ini perlu menghilangkan ketidakpastian hukum yang terkandung dalam norma Pasal 164 ayat (3) UU 13/2003 untuk menegakkan keadilan dengan menentukan bahwa frasa "perusahaan tutup" dalam Pasal 164 ayat (3) UU 13/2003 tetap konstitusional sepanjang dimaknai "perusahaan tutup permanen atau perusahaan tutup tidak untuk sementara waktu". Dengan kata lain frasa "perusahaan tutup" tersebut bertentangan dengan UUD 1945 sepanjang tidak dimaknai "perusahaan tutup permanen atau perusahaan tutup tidak untuk sementara waktu".

Apabila mengacu pada tipe negara hukum yang sesuai dengan kasus tersebut adalah tipe negara hukum formal yang mana segala tindakan pengusaha yang memerlukan bentuk hukum tertentu, harus berdasarkan Undang-Undang. Sebutan lain tipe negara ini adalah negara demokratis yang berlandaskan negara

\footnotetext{
12 Putusan Mahkamah Konstitusi Nomor 19/PUU-IX/2011 hlm. 12.

13 Ibid., hlm. 53.
} 
hukum. Bukti adanya keselarasan tipe negara hukum formal dengan dilanggarnya Hak Konstitusional Warga Negara adalah adanya unsur jaminan hak-hak asasi manusia. Ini berarti tipe negara ini cocok untuk mewujudkan perlindungan hak-hak asasi manusia.

Dimasukannya Hak Asasi Manusia ke dalam konstitusi tertulis juga mempunyai arti pemberian status kepada hak-hak tersebut sebagai hak konstitusional. Konstitusi di negara Indonesia adalah hukum dasar atau hukum fundamental sehingga setiap tindakan negara atau orang perorangan yang bertentangan atau tidak sesuai dengan hak konstitusional harus dibatalkan oleh pengadilan karena bertentangan atau tidak sesuai dengan hakikat konstitusi sebagai hukum dasar (fundamental).

Dari beberapa konsep negara hukum, dan Prinsip HAM dapat diberikan jawaban bahwa Putusan Mahkamah Konstitusi Nomor 19/PUU-IX/2011 dalam kasus Hotel Papandayan merupakan suatu putusan yang tepat atau dalam arti lain telah memberikan cerminan perlindungan hak-hak warga negara, khususnya hak warga negara dalam hal pekerjaan. Hal ini pun dibuktikan dengan dikabulkannya Sebagian permohonan para Pemohon, dan berarti memang terdapat multitafsir dalam Pasal 164 ayat (3) yang mana multitafsir ini merugikan para pekerja.

Negara Indonesia sebagai negara hukum, harus bertindak tegas dengan adanya multitafsir pada Pasal tersebut. Karena pada hakikatnya, negara hukum mempunyai prinsip untuk penjaminan Hak Asasi Manusia. Hak Asasi Manusia ini pun adalah merupakan kewajiban negara untuk melindungi setiap Warga Negara.

Problematika yang terjadi berikutnya adalah apakah Putusan ini akan dilaksanakan oleh pengusaha atau pemberi kerja dan pekerja akan menaati, ini harus menjadi pekerjaan yang serius bagi pemerintah. Walaupun dalam Putusan Mahkamah Konstitusi bersifat final dan binding, yang berarti Putusan tersebut Putusan yang pertama dan terakhir (tidak ada hukum lain) serta tidak hanya mengikat para pihak, tetapi mengikat seluruh warga negara, namun Putusan Mahkamah Konstitusi ini tidak mempunyai kekuatan eksekusi yang mana kekuatan ini dapat memberikan kejelasan tindakan yang seharusnya dilakukan selanjutnya setelah adanya Putusan Mahkamah Konstitusi ini.

Hukum positif yang telah di susun rapi, terstuktur, dan sesuai dengan citacita warga negara, hanya akan menjadi norma yang ada di atas kertas saja, apabila pelaksanaan tidak memiliki organ pelaksana yang bertanggungjawab. Hal ini pun menjadi penting, terkait kewenangan hakim dalam memutus suatu perkara. Hakim disini mempunyai peran penting dalam usaha menjamin kesejahteraan, keselamatan perlindungan setiap warga negara. Putusan Hakim 
sendiri harus didasarkan melalui norma-norma yang berlaku, keyakinan hakim sendiri, dan tidak boleh mendapat intervensi dari pihak manapun. Putusan Hakim ini tidak selamanya mulus atau dapat dikatakan sering terjadi permasalahan di dalam kekuasaan kehakiman di Indonesia.

Berdasarkan putusan Mahkamah Konstitusi tersebut dapat menghadirkan beberapa akibat yang terjadi sebagai berikut: pertama, makna perusahaan tutup disini harus diartikan dalam suatu kejelasan makna agar tidak menimbulkan multitafsir yang bisa berakibat disalahgunakan oleh orang-orang mempunyai tujuan yang ingin merugikan orang lain, dalam halam ini, pekerja/buruh dengan menggunakan frasa perusahaan tutup. Perusahaan tutup harus diartikan perusahaan tutup secara permanen atau selamanya, bukan perusahaan sementara. Sehingga demi mencegah terulangnya kembali penggunaan frasa ini, saya sependapat dengan Mahkamah untuk mengabulkan permohonan para Pemohon untuk adanya peninjauan dan penegasan kembali frasa "perusahaan tutup" agar tidak dimaknai bermacam-macam atau multitafsir. Dalam frasa perusahaan tutup ini memberikan berbagai makna, salah satu contohnya dalam kasus ini, frasa ini digunakan untuk tujuan memberikan PHK kepada para pekerja dengan alasan renovasi, padahal renovasi disini hanya bersifat sementara atau dalam kata lain, tidak secara permanen atau selamanya. Hal ini jelas melanggar Hak Konstitusional warga negara dalam hal bekerja yang telah diatur di dalam Pasal 28D ayat (2) UUD 1945.

Kedua, dalam hal memberikan Pemutusan Hubungan Kerja (PHK) harus dimaknai sebagai upaya terakhir. Hal ini harus dimaknai demikian, untuk memberikan jaminan Hak Konstitusional setiap Warga Negara dalam hal bekerja, jika hak bekerja ini dilanggar, maka jelas sangat melanggar konsep dalam memperoleh pekerjaan, PHK yang dilakukan oleh perusahaan ini, dirasa kurang tepat, karena perusahaan tidak dapat melakukan PHK sebelum menempuh upaya-upaya yang telah ditetapkan oleh UU Nomor 13 Tahun 2003 tentang Ketenagakerjaan.

Ketiga, diajukannya Peninjauan Kembali kepada Mahkamah Agung, dengan adanya bukti baru (novum) yang telah diputus oleh Mahkamah Konstitusi berupa keputusan judicial review yang dilakukan oleh para Pemohon. Namun, bukti baru ini ditolak oleh Mahkamah Agung, dengan alasan Peninjauan Kembali tidak dapat dibenarkan, karena Memori Peninjauan Kembali 5 September 2012 dihubungkan dengan pertimbangan Judex Juris dan Judex Facti, tidak terdapat kekhilafan Hakim atau kekeliruan yang nyata.

Putusan Mahkamah Agung dengan menolak novum baru ini memang tindakan yang tidak salah, karena pada dasarnya novum yang diajukan tidak 
memiliki kekuatan hukum yang dapat mengeksekusi. Sehingga sifat Putusan Mahkamah Konstitusi yang mengadili pada tingkat pertama dan terakhir (final) serta mengikat (binding) seluruh warga negara, hanya sebuah pernyataan semata. Apabila Putusan Mahkamah Konstitusi ingin terwujud secara nyata, maka diperlukan peran pemerintah dan DPR selaku badan yang bertugas pembuat suatu Peraturan Perundang-undangan yang ada di negara Indonesia.

Keempat, pengaturan lebih lanjut terhadap hak-hak pekerja, sebagaimana sifat putusan hakim yang salah satunya declaratoir, yang mana mempunyai arti "menyatakan", hal ini hanya sebuah pernyataan semata, tidak mempunyai kekuatan eksekusi setelah adanya putusan ini. Sehingga apakah putusan ini hanya sebatas tulisan yang ada diatas kertas, bagaimana peran pemerintah Bersama DPR Menyusun suatu peraturan perundang-undangan untuk melindungi setiap warga negara. Pernyataan ini pun harus digarisbawahi agar ada tindakan nyata pemerintah Bersama DPR yaitu dengan melakukan revisi Undang-Undang Nomor 13 Tahun 2003 tentang Ketenagakerjaan, khususnya dalam Pasal 164 ayat (3) tersebut.

Hal ini sesuai dengan akibat hukum dari Putusan MK yang medorong terjadinya proses politik. Proses politik disini menyangkut amandemen atau merubah undang-undang atau membuat undang-undang baru sebagai akibat Putusan Mahkamah Konstitusi yang menyatakan bahwa Pasal yang diujikan bertentangan dengan UUD NRI Tahun 1945. Tindakan nyata ini pun akan membawa kepastian hukum, sebagaimana dalam negara hukum diakui mengenai asas kepastian hukum. Adanya kepastian hukum ini juga menjamin perlindungan Warga Negara dalam melaksanakan berbagai macam masalah yang terjadi dalam kehidupan bernegara, pada persoalan ini terkait hak-hak pekerja untuk mempertahankan haknya dalam bekerja.

Kelima, yang tak kalah penting bagi pekerja, khususnya pekerja yang terkena PHK di Hotel Papandayan yaitu dengan hilangnya mata pencaharian yang seharusnya dilakukan pekerja untuk menunjang kebutuhan sehari-hari. Walaupun Mahkamah mengabulkan sebagian permohonan pemohon, namun pekerja di Hotel Papandayan ini tetap diberi PHK karena Putusan Mahkamah hanya bersifat menyatakan bukan mengeksekusi. Disini pekerja beserta keluarganya harus berpikir lebih keras agar memperoleh pekerjaan Kembali. Pekerja dalam hubungannya dengan Hotel Papandayan rata-rata sudah berusia paruh baya. Hal ini pun menjadi masalah baru bagi diri pekerja. Akibat umum bagi pekerja pada umumnya adalah diperlukan amandemen atau revisi UU Nomor 13 Tahun 2003 terutama pada Pasal 164 ayat (3) ini.

Peran pemerintah dan DPR sangat penting selaku organ yang merancang dan mengesahkan suatu undang-undang di negara Indonesia. Apabila 
pemerintah dan DPR segera merevisi UU terutama pada pasal tersebut. Hal ini sangat memberikan kepastian hukum bagi pekerja karena hak-hak pekerja disini telah pasti diberikan perlindungan oleh negara.

\section{Penutup}

Berdasarkan pembahasan dan analisis terhadap permasalahan, kesimpulan yang dapat diambil adalah sebagai berikut: terdapat multitafsir dalam Pasal 164 ayat (3) Undang-Undang Nomor 13 Tahun 2003 tentang Ketenagakerjaan sehingga hak-hak pekerja dilanggar oleh pengusaha. Kedua, akibat adanya multitafsir terhadap Pasal 164 ayat (3) Undang-Undang Nomor 13 Tahun 2003 tentang Ketenagakerjaan (i) dapat disalahgunakan oleh pengusaha untuk memberikan PHK kepada pekerja/buruh; (ii) pengusaha dalam hal melakukan PHK harus dimaknai sebagai upaya terakhir; (iii) diajukan Peninjauan Kembali; (iv) pengusaha harus bertanggungjawab atas hilangnya mata pencaharian para pekerja.

Adapun saran yang dapat diberikan adalah sebagai berikut: pertama, dalam pembuatan UU seharusnya memperhatikan dan teliti serta menguraikan secara rinci mengenai setiap frasa dalam pasal yang telah disusun, hal ini dilakukan untuk menghindari multitafsir. Kedua, dalam pengujian uji materi UU, pengusaha harus memperhatikan pertanggungjawaban materiil yang berhak diterima oleh pekerja/buruh. Ketiga, Mahkamah Konstitusi dalam menjalankan keputusannya diberikan hak mengeksekusi agar putusan yang bersifat final dan binding, benarbenar menindaklanjuti keputusan tersebut.

\section{Daftar Pustaka}

\section{Buku}

Huda, Ni'matul, Hukum Tata Negara Indonesia, PT. Raja Grafindo Persada, Jakarta, 2005.

, Negara Hukum, Demokrasi \& Judicial Review, UII Press, Yogyakarta, 2005.

Prodjodikoro, Wirjono, Asas-asas Ilmu Negara dan Politik, Eresco, Bandung, 1971.

Sunaryati Hartono, C.F.G. Penelitian Hukum di Indonesia Pada Akhir Abad ke-20, Alumni, Bandung, 1994.

Uwiyono, Aloysius, dkk., Asas-asas Hukum Perburuhan, PT RajaGrafindo Persada, Jakarta, 2014.

Wijayanti, Asri, Hukum Ketenagakerjaan Pasca Reformasi, Sinar Grafika, Jakarta, 2014.

\section{Peraturan Perundang-undangan}

Undang-Undang Nomor 13 Tahun 2003 tentang Ketenagakerjaan 


\section{Internet}

"Karyawan Hotel Papandayan Bandung Kembali Adukan PHK", https://nasional.tempo.co/, diakses tanggal 20 Desember 2020.

"Karyawan Hotel Papandayan Bandung Menolak Pemecatan", https://nasional.tempo.co/, diakses tanggal 13 Januari 2021.

\section{Putusan Pengadilan}

Putusan Mahkamah Konstitusi Nomor 19/PUU-IX/2011 